\title{
Genetic diversity of Norwegian and Lithuanian red deer (Cervus elaphus) populations
}

Irma Pūraitè',

Algimantas Paulauskas ${ }^{1 \star}$,

Olav Rosef ${ }^{1,2}$,

Aniolas Sruoga ${ }^{1}$

${ }^{1}$ Department of Biology,

Vytautas Magnus University,

Vileikos 8, LT-44248 Kaunas,

Lithuania

${ }^{2} A T P$-innovation AS,

3800 Bø i Telemark, Norway
During the last centuries, red deer (Cervus elaphus) have survived a drastic decline in population number which has gone as far as extinction in many regions of the continent. Today's deer population is abundant and widespread, however, affected by re-introduction and keeping isolated animals in enclosures. It is necessary to observe the genetics of these animals and to monitor changes that occur in populations as well as apply the obtained knowledge in creating and restoring the species. This study investigates the levels of genetic diversity of red deer. Muscle and liver samples were obtained from 27 individuals corresponding to 2 red deer populations from Lithuania and Norway. Samples were analyzed by RAPD (random amplified polymorphic DNA) polymerase chain reaction (PCR) using ten primers (ROTH180-01, ROTH-180-02, ROTH-180-03, ROTH-180-04, ROTH-180-05, ROTH-180-06, ROTH-180-07, ROTH-180-08, ROTH-180-09, ROTH-180-10). PCR products were sorted according to their size by electrophoresis in $1.7 \%$ agarose gel. Gel electrophoresis showed that there were 64 polymorphic loci with the fragment size varying from 150 to 3 000. The "TREECON for Windows" programme was used for the estimation of genetic variability. Genetic variability among the red deer separate individuals varied from 0.08 to 0.80 .

Key words: red deer (Cervus elaphus), RAPD, PCR, ROTH-180, genetic diversity

\section{INTRODUCTION}

Subfossil residues indicate that the red deer were in the Eastern Baltic in the early Holocene, and this species was a very widespread one in the mid-Holocene. Late Holocene spread of the game from the northern boundary started to retreat to the south, but still many of them remained in Lithuania until the middle of the second millennium. Subsequently, deer disappeared, and when in Lithuania - not exactly known [9].

Red deer started to reacclimatize in Žagare forests. It is supposed that the initial free-living deer herd there was formed from the animals released by the peasants from Count Naryshkin's enclosures during the First World War.

\footnotetext{
* Corresponding author. E-mail: a.paulauskas@gmf.vdu.lt
}

There is another version stating that deer came from Latvia (in the beginning of the 20th century they were reacclimatized in Kurland). Based on data by Skriba G. (1975), there were nine wild deer herds (micropopulations) in Western Latvia in 1914. One herd occupied the area near Lithuanian border, a few miles from Žagare forests. In 1934, there were 18 red deer counted in Žagare forest.

Before the Second World War, deer reacclimatization was rather inconsistent. In 1935, two deer were released into Trakai district forests and two deer, caught in Latvia in 1939, were brought into Kaišiadorys district forests. After the war, red deer were introduced from Voronezh reserve. Red deer, reintroduced from Voronezh reserve, reacclimatized successfully but, nevertheless, spread slowly [2] to the neighboring areas. In the forests of Southern Lithuania deer came from Poland and the Kaliningrad region. 
Since 1969, Lithuania had started deer capture and relocation to a new place in order to accelerate the spread of the animals. In 1969-1983, eight hundred deer were caught by the method of remote immobilization and released into 28 country district forests. Deer were captured and moved to new locations in Lithuania until 1987. The total number of 1030 deer were caught and moved into other forests. In addition, 38 deer moved to Estonia (in 1979, 1980 and 1987) and 23 animals moved to Russia (1988). Due to introduction, transfer and immigration from the surrounding areas, red deer became an important component of the Lithuanian forest biocenoses.

Today's deer population of Lithuania is abundant and widespread almost in all forests. The population of these animals is an excellent model for studies of genetic effects. Lithuanian fund of red deer genes was affected by the reestablishment, transfer, keeping isolated animals in enclosures, fragmentation and hunting. In recent decades, the ungulate biology, morphology and ecology as well as deer significance to the cultural landscape have been investigated [3]. Deer genetic diversity studies have been launched recently and there isn't much data on the genetic variability of the animals living in Lithuania.

In Norway, the red deer (Cervus elaphus atlanticus) have existed at least since the Subboreal period (5,700$2,600)[5,1]$ and the written records document an abundant population distributed throughout most of Southern Norway until approximately year $1750[7,4]$. In the mid eighteenth century, the Norwegian red deer population declined drastically and until the beginning of the last cen- tury it was confined to only five or six locations along the western coast, counting a few hundred individuals in total at the most extreme $[5,8]$. Since the beginning of the last century, and especially after 1950, the Norwegian red deer population has expanded from the western coast localities, demographically as well as spatially. It is now common in most parts of southern and central Norway with a total population size ranging from 100,000 to 120,000 individuals in 1997 [10, 6]. Many reasons have been suggested for these population fluctuations, including high pressures of predation and hunting from the middle of the eighteenth century $[4,5]$, as well as temporal changes in the use of agricultural land $[1,11]$.

The genetic variability of red deer in Lithuanian and Norwegian populations is not clear. It is necessary to observe the genetics of these animals and to monitor changes that occur in populations in order to apply the obtained knowledge for creating and restoring the species.

\section{MATERIALS AND METHODS}

\section{Sampling and laboratory procedures}

Between 2006 and 2009, hunters sampled tissue from 17 wild red deer from 4 different locations (Ignalina, Molètai, Panevėžys, Ukmergè) in Lithuania and 10 red deer samples were collected by the red deer farm owner in Norway in 2007 (Fig. 1).

Genomic DNA was extracted from frozen liver and muscles using "Genomic DNA Purification Kit \# KO512" (Fermentas, Lithuania), which included lysis, precipitation

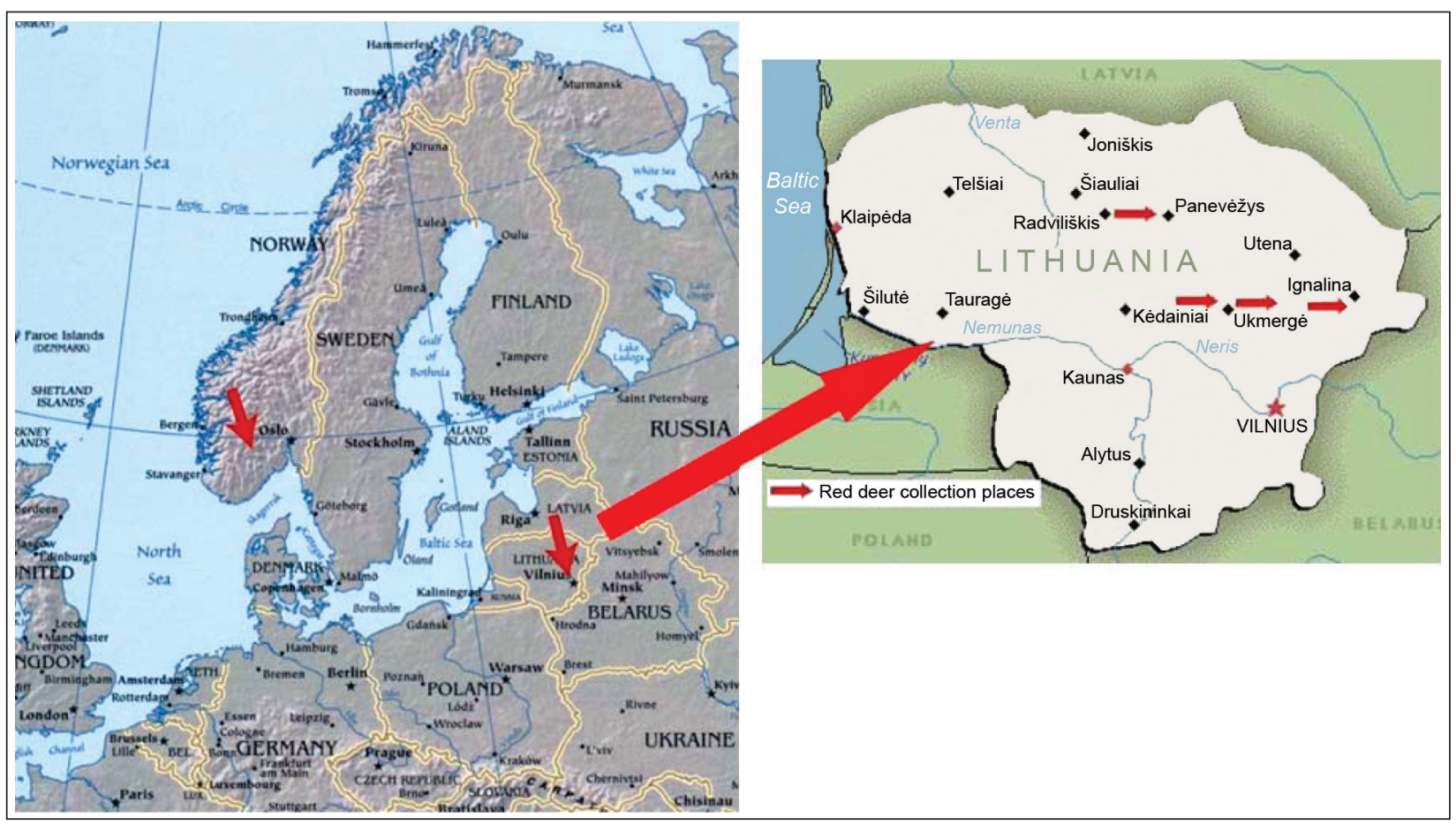

Fig. 1. Sampling localities of Norwegian and Lithuanian red deer 


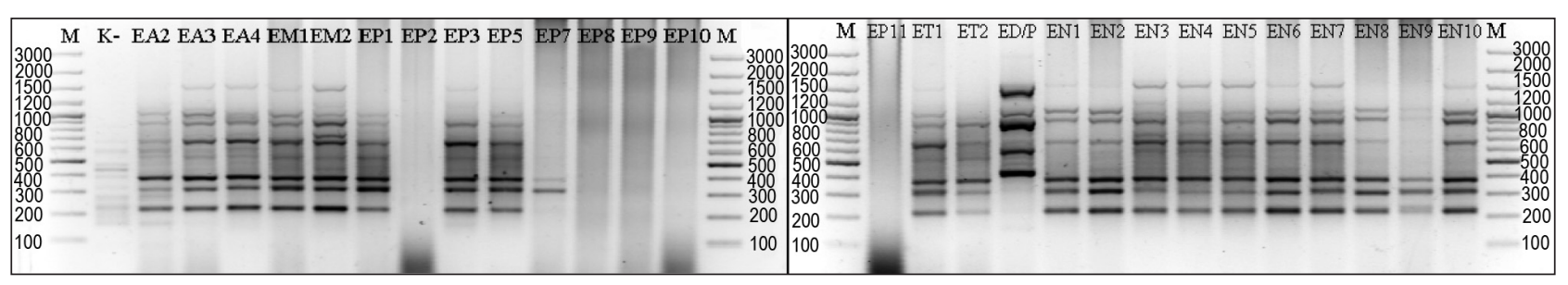

Fig. 2. Electrophoresis of amplified DNA fragments (ROTH-180-09) in 1.7\% agarose gel.

EA2, EA3, EA4 and others - red deer individuals, $\mathrm{M}$ - Gene Ruler 100 bp DNA Lader Plus

and $\mathrm{NaCl}$ solutions. The quality and concentration of DNA were estimated with "Eppendorf BioPhotometer" spectrophotometer and by running electrophoresis in agarose gel.

PCR was performed on a Mastercycler gradient (Eppendorf $)$ in a $25 \mu \mathrm{l}$ reaction mix containing $2 \mu \mathrm{l}(10 \mathrm{pmol} / \mu \mathrm{l})$ ROTH-180 primer, $2.5 \mu \mathrm{l} 0.1 \mathrm{mM}$ dNTP, $2.5 \mu \mathrm{l}$ 10X Taq buffer with $\mathrm{KCl}$ and $\mathrm{MgCl}_{2}, 1 \mathrm{U}$ Taq-polymerase $(5 \mathrm{U} / \mu \mathrm{l}), 13.8 \mu \mathrm{l}$ distill water and $4 \mu \mathrm{l}$ template DNA ( $25 \mathrm{ng}$ ). Thermocycling parameters after predenaturation step at $94{ }^{\circ} \mathrm{C}$ for 3 minutes were 35 cycles with a denaturation step at $94^{\circ} \mathrm{C}$ for 1 minute, annealing step at $49.9-60.1{ }^{\circ} \mathrm{C}$ for 1 minute, elongation step at $72{ }^{\circ} \mathrm{C}$ for $1 \mathrm{~min}$ and the final elongation step at $72{ }^{\circ} \mathrm{C}$ for $2 \mathrm{~min}$.

PCR products were sorted according to their size by electrophoresis in $1.7 \%$ agarose gel with Tris-Borate-EDTA as a running buffer and using a molecular mass marker GeneRuler TM 100 bp DNA Ladder Plus (Fermentas, Lithuania). DNA bands (Fig. 2) were stained with ethidium bromide and photographed under the UV light (Easy Win 32, Herolab, Germany).

\section{Data analysis}

For data analysis, a binary matrix reflecting specific RAPD band presence (1) or absence (0) of a given amplification product in each genotype was generated [12]. The results were analyzed using "TREECON for Windows" [13] program. The relationships among individuals were represented in a UPGMA cluster tree.

\section{RESULTS AND DISCUSSION}

We amplified red deer DNA with ten primers (ROTH-18001, ROTH-180-02, ROTH-180-03, ROTH-180-04, ROTH180-05, ROTH-180-06, ROTH-180-07, ROTH-180-08, ROTH-180-09, ROTH-180-10) and got 63 fragments ranging from 150 to 3000 base pairs (Table 1).

After the deer DNA amplification with ROTH-180-01, ROTH-180-02, ROTH-180-03, ROTH-180-06 and ROTH180-07 primers we didn't get any fragments. It can be concluded that these primers were unsuitable for Lithuanian red deer genetic diversity studies.

We summed the data on the informative primers (ROTH-180-04, ROTH-180-05, ROTH-180-08, ROTH180-09 and Roth-180-10) and using the "TREECON for Windows" programme constructed a red deer dendrogram (Fig. 3). There are three clusters in this dendrogram. "A" cluster is formed from two individuals from Norway EN2 and EN9. These two individuals were the most genetically distant from the other tested ones whose tissue samples were collected in Norway and Lithuania. Cluster "B" encludes individuals who were caught in Panevėžys and Ignalina districts. There is no data where the individual ED / P was caught, but according to the results of the dendrogram it can be concluded that the deer might have belonged to the Ignalina or Panevėžys herds. " $\mathrm{C}$ " cluster is formed from many individuals and the genetic distance between them is not great. This cluster can be divided into two groups:

Table 1. ROTH-180 primers used in our study

\begin{tabular}{|c|c|c|c|c|}
\hline Primer & Sequence & $\begin{array}{l}\text { Annealing } \\
\text { temperature }\end{array}$ & Fragments number & Fragments size (bp) \\
\hline ROTH-180-01 & 5'-GCACCCGACG-3' & $54.7^{\circ} \mathrm{C}$ & 0 & - \\
\hline ROTH-180-02 & 5'-CGCCCAAGC-3' & $50.5^{\circ} \mathrm{C}$ & 0 & - \\
\hline ROTH-180-03 & 5'-CCATGGCGCC-3' & $58.9^{\circ} \mathrm{C}$ & 0 & - \\
\hline ROTH-180-04 & 5'-CGCCGATCC-3' & $49.9^{\circ} \mathrm{C}$ & 11 & $350-1500$ \\
\hline ROTH-180-05 & 5'-ACCCCAGCCG-3' & $56.4^{\circ} \mathrm{C}$ & 10 & $250-2000$ \\
\hline ROTH-180-06 & 5'-GCACGGAGGG-3' & $53.0^{\circ} \mathrm{C}$ & 0 & - \\
\hline ROTH-180-07 & 5'-GCACGCCGGA-3' & $60.1^{\circ} \mathrm{C}$ & 0 & - \\
\hline ROTH-180-08 & 5'-CGCCCTCAGC-3' & $53.6^{\circ} \mathrm{C}$ & 10 & $200-1200$ \\
\hline ROTH-180-09 & 5'-GCACGGTGGG-3' & $54.4^{\circ} \mathrm{C}$ & 15 & $150-3000$ \\
\hline \multirow[t]{2}{*}{ ROTH-180-10 } & 5'-CGCCCTGGTC-3' & $53.0^{\circ} \mathrm{C}$ & 17 & $250-2000$ \\
\hline & Total & & 63 & $150-3000$ \\
\hline
\end{tabular}


Table 2. Red deer genetic distance according to TREECON programme

\begin{tabular}{|c|c|c|c|c|c|c|c|c|c|c|c|c|c|c|c|c|c|c|c|c|c|}
\hline Ind. & 42 & A3 & 44 & M1 & 12 & 1 & P3 & 5 & T1 & ET2 & $/ \mathbf{P}$ & EN1 & N2 & & N4 & N5 & N6 & EN7 & EN8 & N9 & \\
\hline EA2 & & & & & 14 & 26 & & & & & & & & & & & & & & & \\
\hline & & & & & & & & & & & & & & & & & & & & & \\
\hline EA & & & & & & & & & & & & & & & & & & & & & \\
\hline & & & & & & & & & & & & & & & & & & & & & \\
\hline & & & & & & & & & & & & & & & & & & & & & \\
\hline EP & & & & & & 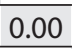 & & & & & & & & & & & & & & & \\
\hline & & & & & & & & & & & & & & & & & & & & & \\
\hline$E P$ & & & & 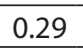 & 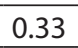 & 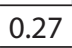 & & & & & & & & & & & & & & & \\
\hline & & & & & & & & & & & & & & & & & & & & & \\
\hline $\mathrm{ET} 2$ & 5 & 33 & 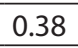 & 33 & 28 & 66 & 0.5 & & 09 & 0.0 & 3 & & & & & & & & & & \\
\hline & & & & 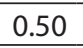 & & 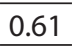 & & & & & & & & & & & & & & & \\
\hline & & & & & & & & & & & & & & & & & & & & & \\
\hline EN & 46 & 46 & 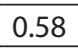 & 1 & 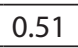 & 3 & 0 & & & & & & & & & & & & & & \\
\hline & & & & & & & & & & & & & & & & & & & & & \\
\hline $\mathrm{EN}$ & 63 & 43 & $\mathrm{C}$ & 44 & & 68 & 05 & & & 0.3 & & & & & & & & & & & \\
\hline $\mathrm{EN}$ & & c & & & & & & & & & & & & & & & & & & & \\
\hline & & & & & & 6 & & & & & & & & & & & & & & & \\
\hline EN & J & c & & & & 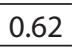 & & & & & & & & & & & & & & & \\
\hline & & & & & & & & & & & & & & & & & & & & & \\
\hline & & & & & & 0.5 & & & & & & & & & & & & & & & \\
\hline EN10 & 0.60 & 0.33 & 0.41 & 0.38 & 0.42 & 0.71 & 0.64 & 0.58 & 0.31 & 0.33 & 0.63 & 0.38 & 0.45 & 0.34 & 0.43 & 0.39 & 0.23 & 0.31 & 0.30 & 0.64 & 0.00 \\
\hline
\end{tabular}

Fig. 3. Phylogenetic tree of the analysed red deer individuals

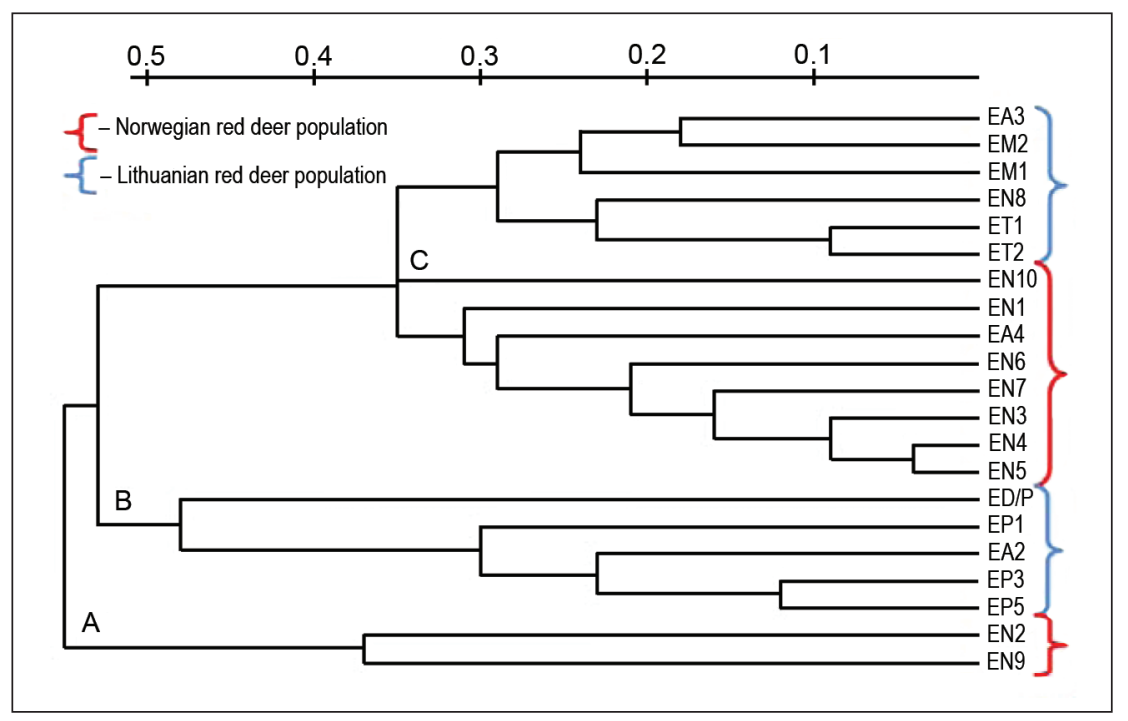

the first group - deer from Norway and one deer from Ignalina region, the second group was composed of 6 red deer: genetically closest ET1 and ET2 individuals from Taujènai, two deer from Moletai , one - from Norway and one from Ignalina region. According to these primers, Norwegian and Lithuanian deer populations are different. Red deer genetic distances are given in Table 2.

\section{CONCLUSIONS}

DNA from 27 red deer representing one Norwegian and four Lithuanian subpopulations was used to amplify with 10 highly polymorphic primers. These primers yielded
63 markers, with an average of 6.3 markers per primer. Fragments were ranging from 150 to 3000 base pairs. The most polymorphic primers were ROTH-180-04, ROTH180-09 and ROTH-180-10 that fit the best to evaluate the genetic diversity of red deer subpopulations.

Genetic distance in deer population ranged between 0.08 and 0.80 . The largest genetic distance was between the Lithuanian and Norwegian individuals, while genetically closest individuals were found in the Norwegian subpopulation.

Red deer subpopulations were investigated by genetic similarity and distance groups in clusters according to their living areas. 


\section{ACKNOWLEDGMENTS}

We express our thanks to the hunters for providing the samples.

Received 2 February 2011

Accepted 28 May 2011

\section{References}

1. Ahlen I. Studies on the red deer, Cervus elaphus L. Scandinavia. III. Ecol investig Viltrevy (Stockh) 1965; 3: 177-376.

2. Baleišis R, Bluzma P, Balčiauskas L. Lietuvos kanopiniai žvèrys (2-as papildytas leidimas). Vilnius, 1998: 1-220 (in Lithuanian).

3. Baleišis R, Bluzma P, Balčiauskas L. Lietuvos kanopiniai žvèrys (3-as papildytas leidimas). Vilnius, 2003.

4. Collett R. Bemerkninger til Norges Pattedyrfauna Nyt Magazin for Naturvidenskaberne, 1877; 22: 93-133 (in Norwegian).

5. Collett R, Hjorten I. Norge (Cervus elaphus atlanticus), nogle biologiske meddelelser. Bergens museums Aarbok 1909; 6: 9-31 (in Norwegian).

6. Forchhammer MC, Stenseth NC, Post E, Langvatn R. Population dynamics of Norwegian red deer: density - dependence and climatic variation. Proc R Soc Lond B Biol Sci, 1998; 265: 341-50.

7. Friis JA. Tilfjelds i ferierne. Cammermeyer, Christiania, 1874 (in Norwegian).

8. Ingebrigtsen O. Hjortens utbredelse i Norge (in Norwegian). Bergens Museums Aarbok 1922-1923 Naturvitensk. Raekke, 1924; 6: 1-58.

9. Ivanauskas T, Linkevičienė N, Maldžiūnaitè S. Vadovas Lietuvos žinduoliams pažinti. 1964.

10. Langvatn R. Hjortens utbredelse i Norge-en oversigt. Villreinen 1988; 1: 1-8 (in Norwegian).

11. Mysterud A, Langvatn R, Yoccoz NG, Stenseth NC. Largescale habitat variability, delayed density effects and red deer populations in Norway. J Anim Ecol, 2002; 71: 569-80.

12. Nei, Masatoshi and Li, Wen-Hsiung. Mathematical model for studying genetical variation in terms of restriction endonucleases. Proc Nat Acad Sci USA, 1979; 76(10): 5269-73.

13. Van de Peer Y, De Wachter Y. TREECON for Windows: a software package for the construction and drawing of evolutionary trees for the Microsoft Windows environment. Comput Applic Biosci, 1994; 10: 569-70.
Irma Pūraitė, Algimantas Paulauskas, Olav Rosef,

Aniolas Sruoga

\section{LIETUVOS IR NORVEGIJOS TAURIŲJŲ ELNIŲ (CERVUS ELAPHUS) POPULIACIJŲ GENETINE IVAIROVE்}

\section{Santrauka}

Šiuo metu tauriųjų elnių populiacijos Lietuvoje yra gausios ir išplitusios, tačiau jų genofondas paveiktas reintrodukcijos, perkèlimo, gyvūnų laikymo aptvaruose, fragmentacijos bei medžioklès. Šių žveriu populiacijos yra puikus genetinių padarinių tyrimų modelis. Siekiant nustatyti tauriųjų elnių genetinę ịvairovę, buvo tiriami 27 individų iš Lietuvos ir Norvegijos kepenų bei raumenų pavyzdžiai. Individai buvo tiriami APPD (atsitiktinai pagausintos polimorfinès DNR) metodika. Tauriụjų elnių genetinès įvairovès analizei buvo panaudota dešimt (ROTH-180-01 - 10) pradmenų. Elektroforezės gelių rezultatai rodo, kad polimorfinių lokusų yra 64, o fragmentų dydis - nuo 150 iki 3000 bazių porų. Gauti fragmentų dydžiai ir skaičiai buvo suvesti $i$ „,TREECON for Windows“ kompiuterinę programą, kuria remiantis ịvertintas genetinis kintamumas. Genetinis kintamumas tarp tirtų tauriųjų elnių individų varijavo nuo 0,08 iki 0,80 .

Raktažodžiai: taurieji elniai (Cervus elaphus), RAPD, PCR, ROTH-180, genetinè itvairové 